
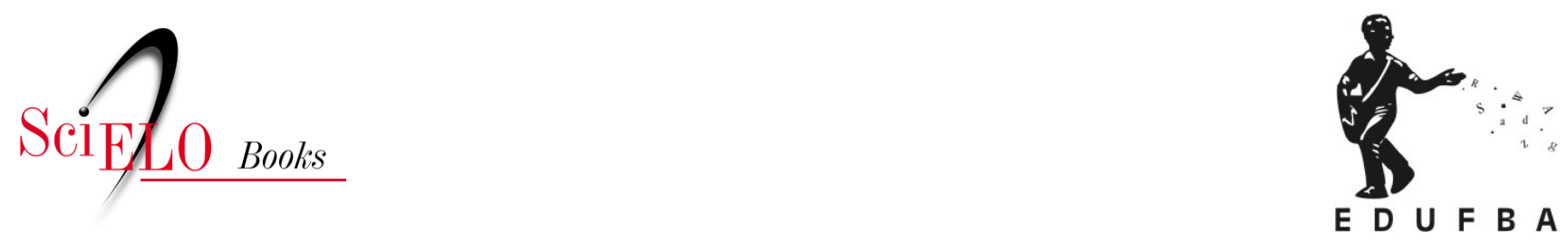

\title{
Reflexões \\ Uma PEC que mata a Educação e a Ciência
}

\author{
Nelson De Luca Pretto
}

PRETTO, N.D.L. Uma PEC que mata a Educação e a Ciência. In: Educações, culturas e hackers: escritos e reflexões [online]. Salvador: EDUFBA, 2017, pp. 172-174. ISBN: 978-85-232-2019-8.

https://doi.org/10.7476/9788523220198.0045.

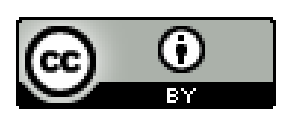

All the contents of this work, except where otherwise noted, is licensed under a Creative Commons Attribution $\underline{4.0 \text { International license. }}$

Todo o conteúdo deste trabalho, exceto quando houver ressalva, é publicado sob a licença Creative Commons Atribição 4.0. 
Na UFBA, além do repositório institucional, a Edufba adotou uma correta política de publicar de maneira aberta toda a sua produção. Assim, se o leitor deseja ter o livro - produzido de maneira primorosa em cuidadosas edições! - ele o comprará, pois terá um bem material, com custo de produção. Já o conteúdo do livro está disponibilizado gratuitamente na internet para todos. Nós, da Faculdade de Educação, temos um projeto, com apoio da Fapesb no início, onde criamos uma plataforma de vídeo, tudo em software livre, disponibilizando toda a nossa produção de forma plena, permitindo e estimulando que as pessoas se apropriem desse material e, remixando, construam mais vídeos, naquilo que tenho chamado de um circulo virtuoso de produção de culturas e conhecimento. Ali é possível encontrar, por exemplo, os depoimentos de grandes educadores baianos, construindo a memória da educação na Bahia, projeto que teve apoio inicial do CNPq.

Publicado no jornal Correio*, Salvador, em 8 de maio de 2013.

\section{Uma PEC que mata a Educação e a Ciência}

Ao logo de mais de 40 anos como professor, tenho me dedicado a causas da educação, da cultura, da ciência e tecnologia, de forma acadêmico-ativista. Ao longo desses anos, nunca vi barbaridade maior do que a proposta pela famigerada PEC 241/55, Emenda Constitucional que modifica a Constituição Cidadã de 1988 e vem sendo denominada pelo governo de PEC dos Gastos Públicos, mas que, para nós, é a PEC do Fim do Mundo.

Foi dramático acompanhar as manobras do governo, oferecendo, entre outras coisas, jantar no Palácio da Alvorada para mais de 200 depu- 
tados federais (eram esperados uns 400!), no domingo, a fim de convencê-los a estar no plenário na segunda (10/10/2016), votando em favor da PEC. O rolo compressor funcionou e, em primeiro turno, ela foi aprovada com 366 votos contra 111 contrários.

Recente estudo emanado do interior do Instituto de Pesquisa Econômica Aplicada (IPEA) - logo depois rechaçado pela nova direção do órgão, gerando reações internas imediatas - indica que o campo da saúde, em um dos cenários projetados, perderia da ordem de R $\$ 743$ bilhões nos 20 anos de vigência da emenda. O Presidente Temer, no vai e vem característico de seu governo, cujo único projeto visível é desmontar os avanços que conquistamos ao logo dos últimos anos, anuncia que pode não ser bem assim, que em quatro ou cinco anos a tal PEC poderá ser revista. Mas o estrago já terá sido feito.

É impressionante a quantidade de associações científicas e sindicatos que têm se manifestado, de forma contundente, contrariamente a essa medida. Como conselheiro da Sociedade Brasileira para o Progresso da Ciência (SBPC), destaco aqui um trecho da carta enviada em 10 de outubro de 2016 a todos os deputados federais, onde dizemos claramente que "[...] reduzir os investimentos públicos em educação, ciência, tecnologia e inovação vai na contramão dos objetivos de efetivamente tirar o Brasil da crise. A experiência mundial nos mostra que, sem investimentos consistentes e permanentes em educação, ciência, tecnologia e inovação, não há desenvolvimento econômico." A carta de uma entidade que congrega mais de 120 sociedades científicas não sensibilizou a manada, o que mostra que o jantar da véspera da votação foi mais sedutor, entre outros tantos possíveis privilégios aos votantes.

É incrível como a própria imprensa tem entrado nessa onda de anuência à PEC, não querendo perceber o risco e o absurdo de um governo que, chegando ao poder sem um único voto sequer para completar um mandato de menos de dois anos, se propõe a tomar decisões que afetarão os próximos 20 anos. Sim, 20 anos! Não estamos falando de um ou dois anos, serão 20 anos de investimentos praticamente congelados em áreas absolutamente fundamentais, como saúde e educação. 
Claro que perto da PEC 241/55, as demais questões terminam sendo até menores, mas ao mesmo tempo não deixam de nos preocupar. Uma delas, com certeza, é a absurda reforma do Ensino Médio que, além de tudo, foi feita via Medida Provisória, atropelando todas as importantes discussões que vêm sendo travadas nos âmbitos acadêmicos e sindicais. Ora, precisamos formar amplamente nossos jovens para que sejam cidadãos críticos e não meramente prepará-los para os exames nacionais ou internacionais (ENEM, PISA ...) ou para a ocupação de carreiras técnicas que, inclusive, certamente serão de baixa qualificação, justo por conta da ausência de investimentos futuros. Não há dúvida de que toda a educação brasileira precisa de grandes transformações e, por isso mesmo, necessita de mais e não de menos investimentos. Essa tem sido nossa labuta e luta cotidiana. A situação é dramática e, como disse o físico da USP e colega Paulo Artaxo, na Folha de São Paulo, de 12/10/2016, a aprovação da PEC 241/55 “[...] será um atraso intelectual muito grande em relação ao mundo". Calar frente a tamanhas barbaridades é ver desmontar tudo aquilo que ao longo de todos esses anos estamos construindo, a duras penas. Calar é trair uma quantidade enorme de alunos que comigo estiveram ao longo dos anos. É tempo de luta, uma luta em defesa do país como um todo e não apenas do setor empresarial.

Se me mantivesse calado eu mesmo me consideraria um traidor de tudo que venho defendendo em sala de aula (oppss, tem a Escola sem Partido!, será que poderei me manifestar?!) ao longo de todos esses anos de profissão. A luta não será pequena, mas quem milita na educação bem sabe que essa luta nunca assim foi. 